\title{
A Histological Study on the Skin and Hairs of PC(poor coat) Mice
}

\author{
Shigetoshi KUROSAWA, Atsuo OGURA, Minako KOURA, Akira NOGUCHI, \\ Yoko NOGUCHI, Yoshie YAMAMOTO, and Kaoru TAKANO
}

\author{
Department of Veterinary Science, National Institute of Health, 2-10-35 \\ Kamiosaki, Shinagawa-ku, Tokyo 141, Japan
}

(Received 27 November 1990/Accepted 26 December 1990)

\begin{abstract}
Light microscopic examinations were done on the skin and hairs of PC (poor coat) mice, maintained as an inbred strain at the National Institute of Health, Japan. The structures of the epidermis, dermis, hair root sheath and the sebaceous glands were normal. Hair bulbs and hair papillae were poorly developed at anagen stage of hair cycle. Having scanty medulla, the hairs were thin and short. The hair cuticle appeared normal. These findings suggest that the defective hair growth in PC mice is caused by deficiencies in cell differentiation and/or proliferation in the hair matrix.
\end{abstract}

\section{貧毛 (PC) マウスの皮膚执よび \\ 毛の構造について}

黒沢重利・小倉淳郎・小浦美奈子・野口章

野口洋子・山本美江·高野

国立予防衛生研究所獣疫部

PC (poor coat) マウスは, 1965年国立予防衛生研究 所でSwiss albino系マウスコロニーに発見された 1 匹 の被毛異常雃をもとに近交化した貧毛マウスである。全 身は長さ1〜2 $\mathrm{mm}$ の波状毛に被われる。正常マウスと 同様, 生後10日までに細く短い毛が体表面を被らように なるが，長い硬毛に発達することはない。触毛（鼻毛） の長さは正常であるが, 波状に屈曲する。これまでにマ ウスの被毛の異常は数多く報告されており，その原因む 多岐にわたっている[2,4]。そこで，PC マウスの貧毛の 性質を明らかにし，現在までに知られている被毛の異常 と比較検討するため, 通常の光学顕微鏡的手法を用い て，その皮庙及び被毛を観察した。

動物は，本研究所にて SPF 条件下で飼育された PC 、
ウス10例（6３00日柃, 雄 5 例雌 5 例), 対照として ICR マウス10例（6〜180日龄）を用いた。これらの材 料から, 毛周期の各 stage を観察できた。動物をエーテ ルにより屠殺した後, 背部および腹部より皮鹿(約 $1 \mathrm{~cm}^{2}$ ) を採取し，10\%リン酸緩衝ホルマリン液で固定した。通 常の方法でパラフィン包埋した後に, 切片を作製し、 一 マトキシリンーェオジン染色を行って観察した。また, 体表部の毛幹の観察のために, 背部の毛を剃刀で採取 し，無染色のままスライドグラスに封入して観察した。 一光学顕徽鏡で観察したPC マウスの皮泊組織（表皮, 真皮, 皮下組織) の構造は, 対照群との差異は認められ ず, 表皮の異常角化および解の増生などは観察されなか った（Fig. 1)。また, 脂腺の構造にも対照群との差は 
認められなかった。

毛包部を組織学的に観察すると，毛周期の成長期 (anagen)の中頃において, ICR マウスでは, 毛乳頭が 入り込んで大きく発達した毛球および太い毛を包んだ毛

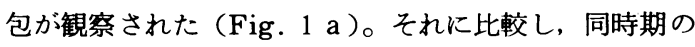
$\mathrm{PC}$ マウスの毛球は明らかに小さく, 毛乳頭の入り込み む少なかった（Fig. 1 b)。毛母細胞は, 毛乳頭に接す る部位, 即ち細胞增殖の行われる部位 (proliferation zone) では, 対照群に比へ, やや不規則に配列し, 細胞 数がやや少なかった。上部の細胞が分化する部位 (differentiation zone) の細胞は, 極端に少なかった。また それに続く毛蹃質の形成も筫弱であった。これらの特徵 は, 最初の毛周期より認められた。表皮に連続する内お。 よび外毛根䩗の形態は，正常であった。成長期の初期お よび停止期 (catagen), 休止期 (telogen) では, PC マ ウスと対照群の毛包に組織学的に大さな相違は無かっ た。毛包数については, ICR マウスと顕著な差は認めら れなかった。

$\mathrm{PC}$ マゥスの体表に現れた毛の構造は, 明らかに異常 であった。対照とした ICR マウスでは，先端部から0.4 $\mathrm{mm}$ 程のところから気泡を含んだ毛髄質が形成され，そ れと同時に毛の太さも增加していた（直径約 $0.04 \mathrm{~mm}$ ) (Fig. 2 a)。毛根部近くでは, 再び細くなり, 毛䯣質 が消失する部分が観察された。また，毛は全長にわた り、ほほ值線的に伸張していた。しかしPCマウスにお いては，気泡がわずかに認められるに過ぎず，毛葡質の 形成が貿弱であることが示された（Fig. 2 b)。この所 見は, 組織切片標本における毛幹部の観察によって子確 認された。毛の長さは $1 \sim 2 \mathrm{~mm}$ と極端に短く, また太 さも約 $0.01 \mathrm{~mm}$ 程度であった。また，明らかな屈曲が認 められた。毛小皮は, 対照群と同様に観察された。

$\mathrm{PC}$ マウスの皮膚および被毛の上記の特徵に雌雄差は 認められなかった。背部と腹部の皮庙で所見は同じであ った。また ICR マウスと同様, 加齢とともに毛包数が 减少する傾向があるが, ヌードマウス (nu) のよ5にほ とんど消失することはない。

これらの観察結果から，PC マウスに打ける被毛の異 常は, $h r$ (ヘアレスマウス) [3]やic[1]のよ5に表皮の 異常から派生するのではなく, 毛自身の構造形成の異常 に起因する可能性が高い。PC マウスにおいても正常、 ウスと同様, 毛周期はあるものの, 毛包の発達は成長期 の前半に停止し, 毛が正常な毛㖪質を形成する前に休止
期に移行し，次の毛に生え換わると考えられる。このた め，体表に現れた毛は細く，健全な毛䯣質を欠くのであ ろら。毛包に直接作用して毛の発達障害を引き起こす 遗伀子として, fz, hid, saなどが知られているが $[4]$, $\mathrm{PC}$ マゥスに観察されるものと同し性質の遗伝子は報告 されていない。通常, 毛が発達するには，毛球における 細胞の増殖および分化が正常に行われ，またそこへ栄養 を運ぶ毛乳頭が十分に発達する必要がある。被毛の異常 が毛母細胞自体あるいは毛乳頭のどちらに起因するか は、コンジェニックマウスを作出し, 皮膚の移植実験な どを行って明らかにする必要があろら。

負毛以外に PC マウスの形質としては，1976年頃より， 浅部のリンパ節（浅鼠径, 腋窩, 浅顏, 䐂下）の腫大が 高頻度に観察されているが，そのほかの組織および臓器 には異常は見つかっていない。交配実験の結果, 負毛と リンパ節腫大の両形質は，別々の遺伝子に支配されてい ることが示されており (未発表), PC マウスの負毛遺伝 子（常染色体上劣性）は，被毛のみに直接影響を与えて いると考えられる。

\section{要䄪}

国立予防衛生研究所で発見され，近交化された筫毛 (PC) マウスの皮届組織および毛の構造を光学顕微鏡的 に観察した。皮店組織, 毛包の毛根䩗扣よび脂腺の構造 は正常であった。一方，毛球部は，毛周期の成長期にお ける発達が覀く, 毛乳頭の入り込みも悪かった。毛は短 くて細く，毛髄質の形成が貧弱であった。毛小皮は形成 されていた。このマウスの負毛の原因は，特に成長期に おける，毛母基細胞の分化あるいは增殖の異常であるこ とが示唆された。

本研究の一部は, 文部省科学研究費補助金 No. 01304025に より行った。

\section{文 献}

[1] Carter, T. C. and Phillips, R. S. (1950). J. Hered, 41, 297-300.

[2] Green, M. C. (1989). In Genetic Variants and Strains of the Laboratory Mouse, 2 nd ed., pp. 12-404, Lyon, M. F. and Searle, A. G. (eds.), Oxford University Press, Oxford.

[3] Mann, S. J. (1971). Anat. Rec., 170, 485-500.

[4] Trigg, M. J. (1972). J. Zool, London, 168, 165-198. 


\section{Explanation of Figures}

Fig. 1. Cross sections of the dorsal skin of an ICR mouse (a) and a PC mouse (b). Anagen stage of hair cycle. The hair bulbs (B) and the dermal papillae (P) are poorly developed in the PC mouse. The structures of the dermis, the epidermis, and the sebaceous glands (S) are normal in the PC mouse as in the ICR
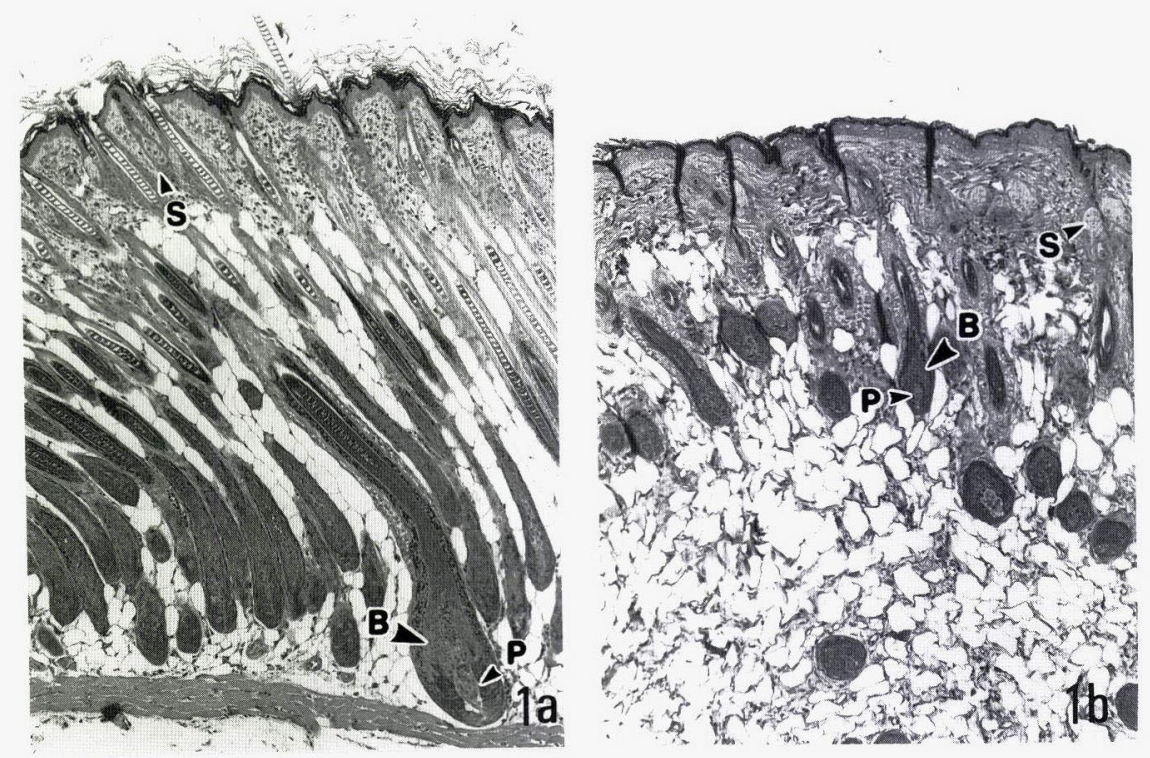

mouse. HE stain $\times 80$

Fig. 2. Photomicrographs of ICR mouse (a) and PC mouse (b) hairs. The PC mouse hair is thin and short, showing apparent curvature. The medulla (M) is not formed in the PC mouse. $\times 80$

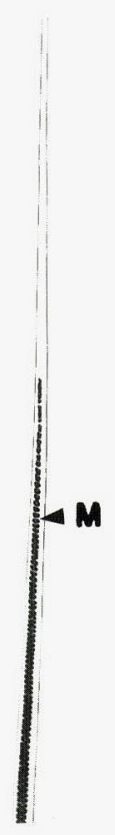

